\title{
Human dermal exposure to galaxolide from personal care products
}

\author{
P. Correia* ${ }^{* \dagger}$, A. Cruz ${ }^{\dagger}$ L. Santos* and A. Alves* \\ *Laboratório de Engenharia de Processos, Ambiente e Energia, (LEPAE), Faculdade de Engenharia da Universidade do Porto, Rua Dr. Roberto Frias, \\ 4200-465, Porto, Portugal and `Núcleo de Investigação em Farmácia, Centro de Investigação em Saúde e Ambiente (CISA), Escola Superior de \\ Tecnologia da Saúde do Porto/Instituto Politécnico do Porto (ESTSP/IPP), Rua Valente Perfeito, 322, 4400-330, Vila Nova de Gaia, Portugal
}

Keywords: galaxolide, HPLC-fluorescence detection, human dermal exposure risk, personal care products, QuEChERS

\section{Synopsis}

Musks are synthetic fragrances applied on personal care and household products as fixatives, by retarding the release of other fragrances with higher volatility. Galaxolide is the most used polycyclic musk since the 90th decade, and it has been detected in several environmental and biological matrices, particularly in human tissues and fluids. For exposure assessment purposes, largemonitoring data need to be obtained and rapid but reliable analytical techniques are requested. The main objective of this study is to develop and validate a new and fast analytical methodology to quantify galaxolide in personal care products and to apply this method to real matrices like skin care products (creams and lotions), shower products (soap bar), hair care products (shampoo and hair conditioner) and oral care products (toothpaste), to evaluate the human dermal exposure risk. A dispersive solid-phase extraction is proposed, using QuEChERS methodology, followed by HPLC with fluorescence detection. Some extraction parameters were studied, like the ratio of sample/solvent amounts, the homogenization time, the salt addition effect and the used sorbents. The validation parameters of the developed method were the following: a linearity range of $0.005-1.002 \mathrm{mg} \mathrm{kg}^{-1}$ sample, a limit of detection of $0.001 \mathrm{mg} \mathrm{kg}^{-1}$ sample, repeatability between $0.7 \%$ and $11.3 \%$ (variation coefficient of six standard injections), an intermediate precision of $2.5 \%$ (variation coefficient of six independent analysis of the same sample), mean recoveries ranging from $65 \%$ (soap bar) to $95 \%$ (body cream) and 3\% of global uncertainty in most of the working range. The time of analysis, including the extraction steps, is $60 \mathrm{~min}$, allowing a throughput of 4 samples $\mathrm{h}^{-1}$. Galaxolide was detected in all of the seven analysed products in concentrations ranging from $0.04 \pm 0.01 \mathrm{mg} \mathrm{kg}^{-1}$ sample (toothpaste) to $280.78 \pm 8.19 \mathrm{mg} \mathrm{kg}^{-1}$ sample (perfumed body cream), which may correspond to a significant estimated daily human dermal exposure of $904 \mu \mathrm{g} \mathrm{day}^{-1}$.

\section{Résumé}

Les muscs synthétiques sont des parfums appliqués sur les produits de soin et les produits ménagers comme fixateurs, qui retardent la libération des autres parfums avec une volatilité plus élevée. Galaxolide est le plus utilisé musc polycyclique depuis 20 ans, et il a été détecté dans plusieurs matrices environnementales et biologi-

Correspondence: Arminda Alves, LEPAE- Faculdade de Engenharia, Universidade do Porto, Porto, Portugal. Tel.: +351 225081883; fax: +351225081449; e-mail: aalves@fe.up.pt ques, en particulier dans les tissus et les fluides humains. Aux fins d'évaluation d'exposition, de données de surveillance importantes doivent être obtenues et des techniques analytiques rapides mais fiables sont donc demandés. L'objectif principal de cette étude est de développer et de valider une nouvelle méthode analytique rapide et de quantifier le galaxolide dans les produits de soins, et d'appliquer cette méthode pour les matrices réelles comme les produits de soins de la peau (crèmes et lotions), les produits de douche (savon), produits de soins capillaires (shampoing et revitalisant capillaire) et les produits d'hygiène buccale (dentifrice), afin d'évaluer le risque d'exposition humaine par voie cutanée. Une extraction en phase solide dispersive est proposée, en utilisant une méthodologie QuEChERS, suivie par HPLC avec détection par fluorescence. Certains paramètres d'extraction ont été étudiés, comme le ratio des quantités d'échantillon/solvant, le temps d'homogénéisation, l'effet de sel d'addition et les adsorbants utilisés. Les paramètres de validation de la méthode mise au point sont les suivants: une plage de linéarité de 0.005 à $1.002 \mathrm{mg} \cdot \mathrm{kg}^{-1}$ d'échantillon, une limite de détection de $0,001 \mathrm{mg} \cdot \mathrm{kg}^{-1}$ de l'échantillon, la répétabilité entre 0,7 et $11,3 \%$ (coefficient de variation de six injections standard), une précision intermédiaire de $2,5 \%$ (coefficient de variation de six analyses indépendantes de l'échantillon même), recouvrements moyens allant de $65 \%$ (savon) à $95 \%$ (crème pour le corps), et $3 \%$ d'incertitude globale dans la plupart des gammes de travail. Le temps d'analyse, comprenant les étapes d'extraction, est de 60 minutes, ce qui permet un débit de 4 samples. $\mathrm{h}^{-1}$. Le galaxolide a été détecté dans l'ensemble des sept produits analysés dans des concentrations allant de $0,04 \pm 0,01 \mathrm{mg} \cdot \mathrm{kg}^{-1}$ (dentifrice) à $280,78 \pm$ $8,19 \mathrm{mg} \cdot \mathrm{kg}^{-1}$ (crème parfumée pour le corps), ce qui peut représenter une importante exposition cutanée quotidienne humaine de $904 \mu \mathrm{g}_{\text {.jour }}{ }^{-1}$.

\section{Introduction}

Musks are synthetic chemicals used in household and personal care products (PCP) to improve its galenic and impart pleasant odoriferous characteristics. Because of their low volatility, they are applied as fixatives, retarding the release of the fragrances from the products and helping to maintain the desired scent of the products. According to their physical-chemical properties, musks are organized in four main groups: nitro musks (NMs), polycyclic musks (PMs), macrocyclic musks (MMs) and alicyclic musks (AMs) [1]. Initially, NMs were the most worldwide used musks, but, in the last decades, some concerns about their toxicity lead to restrictions on their use in Europe [2]. As a consequence, PMs became more 


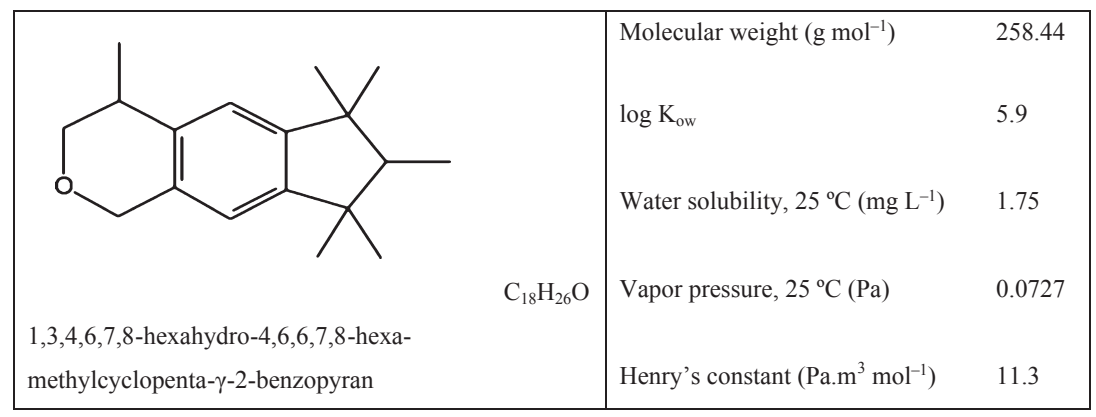

Figure 1 Galaxolide (HHCB) chemical structure, molecular formula, IUPAC chemical name and physical-chemical proprieties [3]: molecular weight, octanolwater partition coefficient $\left(K_{\mathrm{ow}}\right)$, water solubility, vapour pressure and Henry's constant.

popular, particularly galaxolide (HHCB; 1,3,4,6,7-hexahydro4,6,6,7, 8-hexamethylcyclopenta- $\gamma$-2-benzopyran; Fig. 1).

Data only available from 1992 to 2004 [2, 4, 5] may lead to the conclusion that HHCB mean consumption in Europe is slowing down: 2400 tons in 1992, 1482 tons in 1995, 1473 tons in 1998, 1427 tons in 2000 and 1307 tons in 2004. This trend probably appears due to some concerns attributed to PMs [4], and is more significant in the European northern region, whereas in southern countries a slight increase is verified, which can be explained by cultural and marketing differences [2].

The highest environmental contamination by HHCB occurs near cosmetics plants, where it has been found in influent wastewater (max. $595.48 \mu \mathrm{g} \mathrm{L}^{-1}$ ), effluent wastewater (mean $33.54 \mu \mathrm{g} \mathrm{L}^{-1}$ ), sludge (max. $601270 \mu \mathrm{g} \mathrm{kg}^{-1}$ dry weight) and air (max. $4.5 \mu \mathrm{g} \mathrm{L}^{-1}$ ) [6]. But due to its inclusion in almost all PCPs and to its massive use, allied to frequent water rinsing of these products after application, a great part of $\mathrm{HHCB}$ enters the environment through residual water, and it is expected that $77 \%$ of the musks are discharged into the sewer system after used [7]. In fact, HHCB has been found in wastewater treatment plants influents (from 0.029 to $45.4 \mu \mathrm{g} \mathrm{L}^{-1}$ ) and effluents (from bellow 0.0005 to $\left.13.3 \mu \mathrm{g} \mathrm{L}^{-1}\right)$, and in surface and groundwater (0.00009 to $12.47 \mu \mathrm{g} \mathrm{L}^{-1}$ ) in several countries of Europe, America and Asia [2, $4,5,7-14]$, as well as in drinking water from concentrations bellow 0.03 to few $\mu \mathrm{g} \mathrm{L}^{-1}[8,15]$. HHCB has also been found in sewage sludge of wastewater treatment plants all over the world, from 1.4 to $63000 \mu \mathrm{g} \mathrm{kg}^{-1}$ dry weight (dw) [2, 4, 5, 7, 16-19], and in sediments and suspended matter, from 0.2 to $13722 \mu \mathrm{g} \mathrm{kg}^{-1} \mathrm{dw}$ $[2-4,18,19]$. This bound of HHCB to organic matter is mainly explained by the high octanol-water partition coefficient, $\log \mathrm{K}_{\mathrm{ow}}$, of about 6 , and its relatively low water solubility of $1.75 \mathrm{mg} \mathrm{L}^{-1}$ (Fig. 1) [3]. Therefore, soil adsorption of HHCB is also expected, from the deposition of biological sludge as a land application, and real measured concentrations have already been found above $1 \mu \mathrm{g} \mathrm{kg}^{-1} \mathrm{dw}$, and it is also known that HHCB persists in soils at least for 6 months after application [14]. Analysing other physicalchemical properties (Fig. 1) like vapour pressure, $0.0727 \mathrm{~Pa}$, and Henry's constant, $11.3 \mathrm{~Pa} \mathrm{~m}^{3} \mathrm{~mol}^{-1}$ [3], it is expected that $\mathrm{HHCB}$ is easily volatilized [20], and consequently, it has been found in indoor air, from 47.1 to $1256 \mathrm{ng} \mathrm{L}^{-1}$ [21-24], outdoor air, from 1.1 to $344306 \mathrm{ng} \mathrm{L}^{-1}[22,25,26]$ and dust, from 0.4 to $11400 \mu \mathrm{g} \mathrm{kg}^{-1}[17,21,27]$.

Either from water, air or soils, HHCB reaches the biological food chain and has been found in several biological matrices, from
0.00052 to $190 \mathrm{mg} \mathrm{kg}^{-1}[3,9,17,18,28-31]$, mostly of them aquatic fauna samples. Finally, $\mathrm{HHCB}$ has also been found in human matrices like blood, from below 0.003 to $6900 \mathrm{ng} \mathrm{L}^{-1}$ [32-36], breast milk, from bellow 30 to $3600 \mathrm{ng} \mathrm{L}^{-1}$ [36] or below 5 to $108000 \mathrm{ng} \mathrm{g}^{-1}$ fat [32, 37-39] and human fat, from 6.1 to $189000 \mathrm{ng} \mathrm{kg}^{-1}$ fat $[28,32]$.

The major source of human exposure to musks is expected to be the dermal application, especially from intentional use of cosmetics and if these products are used on a regular basis and are not rinsed off after application (leave-on products) [36, 38, 40,41]. There is a limited information on dermal absorption rates for HHCB, but an in vitro study with human skin showed low absorption (about $0.4 \%$ ) of the applied dose [32]. This was confirmed by in vivo studies with human and rat skin that showed some percutaneous absorption $(<2 \%)$, although low dermal permeation and distribution [42] or negligible skin permeability was verified [43]. Nevertheless, other in vivo studies showed a HHCB absorption of about $40 \%$ by human skin [32] and $14 \%$ by rat skin [44]. Additionally, it is expected that $22 \%$ of the applied dose of HHCB will evaporate from the skin [42]. Inhalation exposure can also occur [36, 45], but it appears to represent a minor route of exposure [32, 40].

Although lots of studies have been conducted about the presence of HHCB on different environmental and biological compartments, there are few reports that refer the detection of this musk in PCPs $[41,46-50]$. On these cases, there are some differences between the results obtained in Asia, America or Europe (Table I). For instance, in China, the highest $\mathrm{HHCB}$ mean concentration was found in perfumes [50] and in hair care products [47]. This last study detected trace levels of HHCB in a toothpaste (Table I), suggesting that the use of this product is a minor source of exposure to HHCB [47]. Nevertheless, a work performed in USA concluded that the exposure to $\mathrm{HHCB}$ varies a lot due to the wide range of concentrations found in each group of products, and the highest mean concentrations of HHCB were found in perfumes, body lotions and anti-perspirants (Table I). All of those PCPs are leaveon products, which enhances the risk of human dermal exposure [41]. In Europe, a Belgium study found higher HHCB concentrations also on perfumes and deodorants [46]. Additionally, as mentioned previously, the use of HHCB is greater in south Europe than in north regions $[2,4]$. So, it is crucial to study these aspects in southern Europe, even at a regional scale, measuring data that provides actual information, to evaluate the human exposure risk in this region, namely in Portugal. The studies referred previously can contribute to a human risk exposure assessment to $\mathrm{HHCB}$, but the 
Table I Determination of galaxolide (HHCB), tonalide (AHTN), musk ketone (MK) and musk xylene (MX) in different personal care products (PCPs): extraction and analytical methods, limits of detection (LOD) and quantification (LOQ), recovery percentages and concentrations of HHCB [41, 46-50]

\begin{tabular}{|c|c|c|c|c|c|c|}
\hline Musk & PCPs & Extraction method & Analytical method & HHCB LOD/LOQ & HHCB recovery (\%) & $\begin{array}{l}\text { HHCB concentration } \\
\text { ( } \mathrm{mg} \mathrm{kg}^{-1} \text { sample) }\end{array}$ \\
\hline $\begin{array}{l}\text { HHCB } \\
\text { AHTN [41] }\end{array}$ & $\begin{array}{l}\text { Perfumes } \\
\text { Lotions/creams } \\
\text { Anti-perspirants } \\
\text { Shaving cream } \\
\text { Hair styling } \\
\text { Soap bar } \\
\text { Shower gel } \\
\text { Shampoo } \\
\text { Hair conditioner }\end{array}$ & -Extraction (hexane) & $\begin{array}{l}\text { GC - MS } \\
\text { Run time } 51 \text { min } \\
\text { (HHCB Rt n.a.) }\end{array}$ & $\begin{array}{l}\text { LOD } 0.005 \mathrm{mg} \mathrm{kg}^{-1} \\
\text { sample }\end{array}$ & n.a. & $\begin{array}{l}<\text { LOD }-4990 \\
<\text { LOD }-3740 \\
0.801-2250 \\
<\text { LOD }-1230 \\
12.9-855 \\
0.171-456 \\
<\text { LOD }-104 \\
<\text { LOD }-122 \\
<\text { LOD }-97\end{array}$ \\
\hline $\begin{array}{l}\text { HHCB } \\
\text { AHTN } \\
\text { MK } \\
\text { MX [50] }\end{array}$ & $\begin{array}{l}\text { Perfumes } \\
\text { Shower products } \\
\text { Hair care } \\
\text { Lotions/creams } \\
\text { Toothpastes }\end{array}$ & $\begin{array}{l}\text {-Extraction (hexane) } \\
\text {-SPE clean-up } \\
\quad \text { (silica/alumina column) }\end{array}$ & $\begin{array}{l}\text { GC - MS } \\
\text { Run time } 35 \text { min } \\
\text { (HHCB Rt n.a.) }\end{array}$ & $\begin{array}{l}\text { LOQ } 0.006 \mathrm{mg} \mathrm{kg}^{-1} \\
\text { sample }\end{array}$ & $78 \%$ & $\begin{array}{l}500-1000 \\
0.1-1000 \\
10-500 \\
0.1-10 \\
0.001-0.1\end{array}$ \\
\hline $\begin{array}{l}\text { HHCB } \\
\text { AHTN } \\
\text { MK } \\
\text { MX [47] }\end{array}$ & $\begin{array}{l}\text { Hair care } \\
\text { Lotions/creams } \\
\text { Makeup } \\
\text { Shower gel } \\
\text { Soap bar } \\
\text { Toothpastes }\end{array}$ & $\begin{array}{l}\text {-Extraction (hexane) } \\
\text {-LLE (ethyl acetate/hexane) } \\
\text {-SPE clean-up } \\
\quad\left(\text { silica columns } / \mathrm{Na}_{2} \mathrm{SO}_{4}\right)\end{array}$ & $\begin{array}{l}\text { GC - MS } \\
\text { Run time } 60 \text { min } \\
\text { (HHCB Rt n.a.) }\end{array}$ & $\begin{array}{l}\text { LOQ } 0.00301 \mathrm{mg} \mathrm{kg}^{-1} \\
\text { sample }\end{array}$ & $\begin{array}{l}82 \%(0.1 \mu \mathrm{g} \text { spike }) \\
92 \%(1 \mu \mathrm{g} \text { spike })\end{array}$ & $\begin{array}{l}<\mathrm{LOQ}-1010 \\
<\mathrm{LOQ}-732 \\
<\mathrm{LOQ}-72.8 \\
<\mathrm{LOQ}-63.3 \\
0.08-38.7 \\
<\mathrm{LOQ}-0.02\end{array}$ \\
\hline $\begin{array}{l}\text { HHCB } \\
\text { AHTN } \\
\text { MK } \\
\text { MX [46] }\end{array}$ & $\begin{array}{l}\text { Perfumes } \\
\text { Deodorants } \\
\text { Lotions/creams } \\
\text { Shower products } \\
\text { Hair care }\end{array}$ & $\begin{array}{l}\text {-Extraction (hexane/water) } \\
\text {-SPE clean-up } \\
\quad\left(\text { silica columns and } \mathrm{Na}_{2} \mathrm{SO}_{4} \text { ) }\right.\end{array}$ & $\begin{array}{l}\mathrm{GC}-\mathrm{MS} \\
\text { Run time } 42 \mathrm{~min} \\
\text { (HHCB Rt } 18 \mathrm{~min})\end{array}$ & $\begin{array}{l}\text { LOQ } 0.017 \mathrm{mg} \mathrm{kg}^{-1} \\
\text { sample }\end{array}$ & $\begin{array}{l}98 \%\left(500 \mathrm{ng} \mathrm{g}^{-1}\right. \\
\text { sample spike) } \\
110 \%\left(6 \mathrm{ng} \mathrm{g}^{-1}\right. \\
\text { sample spike })\end{array}$ & $\begin{array}{l}30-22000 \\
5-1000 \\
0.020-600 \\
0.020-400 \\
0.05-100\end{array}$ \\
\hline HНCB [49] & After shave & $\begin{array}{l}\text {-LLE (ethanol) } \\
\text {-Dilution (water) }\end{array}$ & $\begin{array}{l}\text { HPLC - FL } \\
\text { Run time } 35 \text { min } \\
\text { (HHCB Rt } 33 \text { min) }\end{array}$ & LOD $5 \mu \mathrm{g} \mathrm{L}^{-1}$ & n.a. & n.a. \\
\hline $\begin{array}{l}\text { HHCB } \\
\text { AHTN [48] }\end{array}$ & Perfume & $\begin{array}{l}\text {-LLE (hexane/water) } \\
\text {-SPE clean-up (silica column) } \\
\text {-Dilution (methanol) }\end{array}$ & $\begin{array}{l}\text { Capillary electrophoresis } \\
\text { Run time } 45 \text { min } \\
\text { (HHCB Rt } 28 \text { min) }\end{array}$ & $\begin{array}{l}\text { LOD } 49 \mathrm{mg} \mathrm{L}^{-1} \\
\text { LOQ } 147 \mathrm{mg} \mathrm{L}^{-1}\end{array}$ & $90-116 \%$ & 14500 \\
\hline
\end{tabular}

GC-MS, gas chromatography with mass spectrometer detection; Rt, Retention time; n.a., not available; LLE, liquid-liquid extraction; LOQ, limits of quantification; SPE, solid-phase extraction.

social realities differ from one location and culture to another, leading to the existence of distinct PCPs and usage patterns. There are also few reports about the use habits of PCPs like creams/lotions, cosmetics, deodorants, bath and hair care products $[40,51,52]$. Additionally, the PCPs producers are not legally obliged to discriminate the composition of fragrances mixtures used on their formulations and these mixtures [53]. Therefore, for exposure assessment purposes, large-monitoring data need to be obtained, namely HHCB concentrations in PCPs.

Personal care products usually have a pleasant fragrance that is imparted by perfumed oils on its composition. These perfume oil is a mixture of several synthetic fragrances that are used to simulate natural desirable odours. The perfume oil quantities used in each product are extremely variable and depend on the kind of application of the product (skin, hair, and mouth) and the target population (adults/children, men/women). For instance, toothpaste has a small amount of flower and fruit fragrances, combined with flavourings, like peppermint and others, that are responsible for its characteristic scent [54]. Most of PCPs are solutions, suspensions and emulsions, applied in the skin, hair and mucosa. The most complex ones are emulsions that are stable systems of two insoluble liquids, one dispersed in the form of fine droplets (dispersed or inner phase) within the other (closer or outer phase). When the inner phase is composed by water and soluble compounds, it forms a water in oil $(\mathrm{W} / \mathrm{O})$ emulsion, whereas when the inner phase is composed by oil and soluble compounds, it forms a oil in water $(\mathrm{O} / \mathrm{W})$ emulsion. Lotions and creams are emulsions $\mathrm{O} / \mathrm{W}$ or $\mathrm{W} / \mathrm{O}$, and the maximum percentage of disperse phase in a stable emulsion is considered to be $72.5 \%$. To enable emulsion stability, an emulsifier is needed, a compound with higher solubility in the outer phase than in the inner phase, which forms a layer between the two phases [54]. Such distinctive characteristics of the PCPs that incorporate musks in their formulation pose a complex analytical challenge, to develop analytical methods able to quantify HHCB in a wide range of products.

Some analytical methods have been published for the extraction and the detection of HHCB in PCPs [41, 46-50], but almost all are based in liquid-liquid extraction (LLE) with hexane, sometimes followed by clean-up procedures (e.g. silica columns) and gas chromatography with mass spectrometer detection (GC-MS) as 
shown in Table I. These methods are applied to several types of products, like ethanolic and other solutions (perfumes, shampoo and shower gel), emulsions (lotions, creams, conditioners and toothpaste) and solid surfactants (bar soap), but they are time dispending methods, with high solvent consumption and sample manipulation, which leads to higher global uncertainties associated with final results. Most of the referred studies do not perform an uncertainty study, which is particularly important if the detected concentrations are in the frontiers of the detection limits of the methods.

In the this study, HHCB is extracted applying a new extraction method, named QuEChERS, which reduces some of the problems associated to the other referred methods and enables HHCB screening in a great number and variety of samples. These method, originally applied to pesticides extraction from fruits and vegetables [55], dues its name to the association of the terms Quick, Easy, Cheap, Effective, Rugged and Safe method. It is based in three simple steps, each one performed in a polypropylene (PP) conical tube, combined as an extraction, drying/partitioning and dispersive solidphase extraction (dispersive-SPE) method. The first step is the extraction using an adequate solvent, usually acetonitrile, followed by a drying/partitioning step, with salts as magnesium sulphate, $\mathrm{MgSO}_{4}$ and sodium acetate or sodium chloride. A last dispersiveSPE clean-up step uses sorbents like primary and secondary amine exchange polymer material (PSA), and octadecylsilane (also known as C18) or graphitized carbon black (GCB). The choice of salts and sorbents used is based on the analytes and also on matrices characteristics.

As far as the authors know, the QuEChERS methodology has never been applied to the analysis of musks, particularly HHCB, in PCPs. Besides the new method proposal, this work intends to display a complete set of validation parameters, including the global uncertainty associated with the results. This analytical method may be used in the future for exposure assessment purposes applied to a large number and type of personal care and household products.

\section{Methods}

\section{Chemicals and samples}

Seven PCPs were analysed, including two body creams, a body lotion, a shampoo, a soap bar, a hair conditioner and a toothpaste. Galaxolide (HHCB) was obtained at $50 \%$ diluted in diethyl phthalate (DEP), from SAFC (St. Louis, USA). A working standard solution at $60 \mathrm{mg} \mathrm{L}^{-1}$ was prepared in absolute ethanol (proanalysis grade, from Riedel-de Haën, Honeywell Specialty Chemicals Seelze GmbH, Hanover, Germany), as well as a stock solution at $600 \mathrm{mg} \mathrm{L}^{-1}$ in acetonitrile (HPLC isocratic grade, from VWR International, Pennsylvania, PA, U.S.A.). These solutions were used for calibration purposes and for extraction spikes (recovery assays), respectively, and both were stored in the dark at $-4^{\circ} \mathrm{C}$.

The HPLC mobile phase was prepared with deionized water and acetonitrile (the same as previously referred), acidified with glacial acetic acid (100\%), pro-analysis grade, from Pronalab (Tlalnepantla, Mexico).

The extraction solvent was acetonitrile (the same as previously referred). Other tested cosolvents for extraction were methanol (HPLC isocratic grade, from VWR International), acetic acid (the same as previously referred) and deionized water.
The extraction salts and sorbents (named QuEChERS), ECMSSA50CT (6000 mg $\mathrm{MgSO}_{4}, 1500 \mathrm{mg}$ sodium acetate) and ECMPSC1815C (900 mg $\mathrm{MgSO}_{4}, 300 \mathrm{mg}$ PSA, $150 \mathrm{mg} \mathrm{C} 18$ ), were purchased from UCT (Bristol, UK).

\section{Extraction method (QuEChERS)}

The extraction method was adapted from a previous study [55], developed for pesticides. For the method development, four parameters were investigated: (i) type of solvent and necessity of cosolvent, (ii) ratio sample/solvent amounts, (iii) homogenization time and (iv) salts and sorbents for sample drying/partitioning and clean-up steps.

The extraction method is described below. For solid matrices, as soap bar, preliminary trituration in a mortar was necessary. Pre-treated solid samples and liquid/semi-liquid samples were rigorously weighed $(2 \mathrm{~g})$ directly into a PP tube with conical bottom (Falcon, $50 \mathrm{~mL}$ ), and $5 \mathrm{~mL}$ of water were added as cosolvent. The mixture was shaked for $3 \mathrm{~min}$, with a vortex mixer (IKA Vortex Genius 3, IKA ${ }^{\circledR}$ Werke GmbH \& Co. KG, Stanfen, Germany) at maximum speed, and acetonitrile $(15 \mathrm{~mL})$ was added as extraction solvent. Extraction proceeded with a similar shaking step of $3 \mathrm{~min}$ and ultrasounds (P-Selecta ULTRASONS-H, JP SELECTA Laboratory Equipment Manufacturer, Barcelona, Spain) for $10 \mathrm{~min}$. The drying/partitioning step was performed with the QuEChERS salts (ECMSSA50CT), which were added and immediately mixed, to avoid conglomerates formation, for $3 \mathrm{~min}$ in the vortex. To enable total phase separation, centrifugation was performed at $1147.9 \mathrm{~g}$-force for $10 \mathrm{~min}$ (Hettich Zentrifugen Rotofix 32 A, Andreas Hetich GmbH \& Co. KG, Tuttlingen, Germany). The upper layer was transferred to a $50-\mathrm{mL}$ PP tube, and the addition of the QuEChERS sorbents (ECMPSC1815C) enabled the dispersive-SPE clean-up, by vortexing for $3 \mathrm{~min}$, followed by centrifugation (1147.9 g-force, $10 \mathrm{~min}$ ). The upper layer was collected in a $50-\mathrm{mL} \mathrm{PP}$ tube, and, if the extract analysis was not performed immediately, extracts were stored in a freezer $\left(-18^{\circ} \mathrm{C}\right)$ for HPLC-FL analysis. All samples were, at least, four times extracted for quantification purposes and two times for recovery tests.

\section{Blank issues/Quality assurance}

$\mathrm{HHCB}$ can be found in many consumer products, as personal care and household products. Therefore, care was taken by the analyst not to wear personal products that contained fragrances. Glassware materials were washed using only organic solvents and water. To avoid cross-contamination when handling samples, gloves were used by the analyst and changed for each product. All the materials and reagents used in the analysis were proved to be free of interferences, by performing two extraction blanks, for no HHCB was detected (below limits of detection [LOD]).

MICROSOFT EXCEL $2007^{\circledR}$ software program (Microsoft Corporation, Readmond, Washington, USA) was used for all statistical work.

\section{Chromatographic analysis}

HHCB was analysed by high-pressure liquid chromatography with fluorescence detection, HPLC-FL [49]. An eight-point calibration curve was constructed by diluting the $\mathrm{HHCB}$ stock solution (60 $\mathrm{mg} \mathrm{L}^{-1}$ in ethanol), in mobile phase, at concentrations ranging from 1.00 to $200.40 \mu \mathrm{g} \mathrm{L}^{-1}(1.00,5.01,10.02,40.08,80.20$, 120.24, 160.32 and $200.40 \mu \mathrm{g} \mathrm{L}^{-1}$ ) equivalent to 0.005 to $1.002 \mathrm{mg} \mathrm{kg}^{-1}$ sample. 


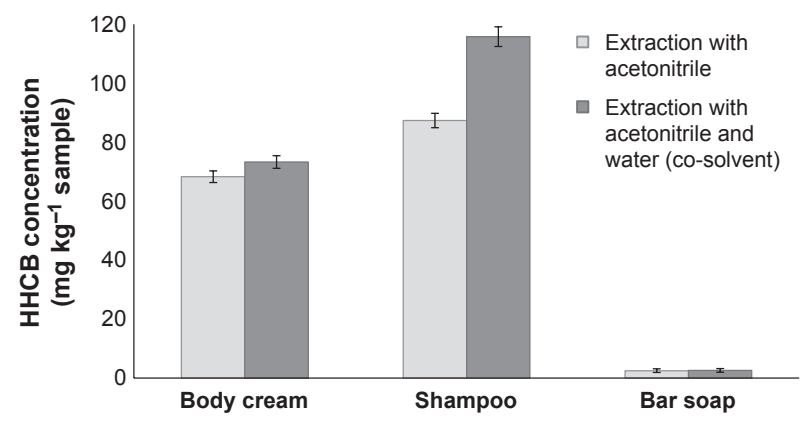

Figure 2 Galaxolide (HHCB) concentration ( $\mathrm{mg} \mathrm{kg}^{-1}$ sample) of three different personal care products (body cream, shampoo and bar soap): extraction using only acetonitrile _ compared to the extraction with cosolvent (water) addition.

Extracts were previously filtered by a syringe filter (PTFE membrane, $0.2 \mu \mathrm{m}$ pore, $13 \mathrm{~mm}$ diameter, VWR International) and diluted with mobile phase, whenever the analyte concentration exceeded the higher concentration of the calibration curve.

Standard solutions and extracts were analysed by HPLC (MerckHitachi L6200A Intelligent Pump, Hitachi, Tokyo, Japan) with a Merck column LiChroCART ${ }^{\circledR}$ 250-4- LiChrospher $^{\circledR} 100$ RP- 18 ( $5 \mu \mathrm{m}$ ) (Merck, Whitehouse Station, NJ, USA). A manual injection volume of $120 \mu \mathrm{L}$ was used (SGE Analytical Science, $250 \mu \mathrm{L}$, 250 F-LC, SGE Analytical Science Pty Lda, Victoria, Australia) and the mobile phase, acetonitrile/water (acidified with acetic acid $17 \mathrm{mM}$ ) at the ratio $80: 20$, respectively, was kept in isocratic mode, at $1 \mathrm{~mL} \mathrm{~min}{ }^{-1}$. Detection was performed at $\lambda_{\text {excitation }}=280 \mathrm{~nm}$ and $\lambda_{\text {emission }}=310 \mathrm{~nm}$ (Merck-Hitachi F-1080 Fluorescence Detector and Interface Detector D-7000, Hitachi, Tokyo, Japan). Chromatograms were analysed with a MERCK-HITACHI MODE D-7000 CHROMATOGRAPHY Data Station Software (Hitachi, Tokyo, Japan).

Total run time was $15 \mathrm{~min}$, and the HHCB peak showed a retention time of 12 min (Fig. 2).

\section{Results and discussion}

Few publications exist concerning the quantification of HHCB in PCPs $[27,41,46,48-50]$. On the current study, six types of PCPs were analysed (body creams, body lotion, shampoo, soap bar, toothpaste and hair conditioner), and the main purpose was to obtain a fast, but reliable analytical method, that will enable the HCCB screening in a large number of samples in several types of PCPs, for further human exposure assessment.

\section{Extraction method development}

Due to the complex composition of PCPs, extraction and clean-up procedures have to be adopted before the chromatographic determination by either GC or HPLC methods. The extraction of HHCB in PCPs has been mostly performed with hexane, by vortex shaking or sonication and centrifugation steps (Table I). This procedure is, at least, twice repeated, and the extracts are then combined [27, $41,46,48,50]$. Further clean-up implies additional steps of solvent evaporation, SPE with silica columns, another solvent evaporation and recovery with an appropriate solvent $[27,46,48,50]$. These procedures result in time dispending methods, high solvent consumption and increased uncertainty of the results due to sample manipulation and additional costs of the analysis.

In this study, the basis for the method development was the previous application of QuEChERS to pesticides [55], where the extraction time is reduced comparatively to LLE extraction procedures, the solvent consumption is diminished, the solvent is environmentally compatible and the costs are accessible to allow future HHCB screening in a large number of samples. The original method, described by Anastassiades et al. (2003), was developed for pesticide extractions from food samples, where most of the analytes are polar substances, whereas HHCB is much less polar. Nevertheless, some less polar pesticides have also been successfully extracted with this method, and therefore, it was thought that an improvement of the QuEChERS methodology could be performed, to allow the determination of HHCB in PCPs. The PCPs formulation presents a challenge, whenever such different matrices, that include ethanolic solutions, emulsions and solid surfactants, are to be analysed by the same method. As a result of the samples composition, some parameters were adapted from the original method [55], essentially sample/solvent amount, shaking time, as also salts and sorbents used on sample drying/partitioning and clean-up steps.

\section{Selection of the extraction solvent}

Because almost all of the fragrance compounds have an oily nature [54], it was expected that, similarly, musks would be more easily extracted by non-polar solvents. Acetonitrile was found adequate, because of its low viscosity and intermediate polarity, and also its effectiveness as mobile phase in reversed-phase liquid chromatography. Additionally, acetonitrile has a low volatility that allows manipulation without great volume changes [55].

The first group of products tested was lotions and creams, and, in this case, the use of acetonitrile resulted in product homogenization. This solvent was also adequate to the shampoo and the soap bar. However, the samples of hair conditioner and toothpaste were not efficiently homogenized by acetonitrile, and therefore, a cosolvent had to be used. Pursuing that objective, three solvents were tested: acetic acid, methanol and water. Only with this last solvent, the referred products were homogenized, and so, $5 \mathrm{~mL}$ of water was added prior to acetonitrile. Water enables the destruction of $\mathrm{O} / \mathrm{W}$ emulsions (in this case, hair conditioner or toothpaste), and a consequent efficient extraction. To uniform the extraction method, water addition was also applied to the other products, a body cream, a shampoo and a soap bar, without loss of efficiency, as it is shown in Fig. 2.

Effect of the sample and solvent amount

To maximize the surface area and ensure better extraction efficiencies during shaking, some samples needed pre-treatment, as the soap bar that was triturated in a mortar. Due to its consistency (semi-solid or liquid), the other products tested in this study were used directly.

The tested sample amounts were 2 and $10 \mathrm{~g}$, but the latter resulted difficult to fit inside the 50-mL PP tube, due to the low density of almost all PCPs. But the lower sample amount could compromise the desirable low limit of detection of the method. Reproducibility and accuracy were improved, when the sample weight was $2 \mathrm{~g}$, and, therefore, it was chosen. The low samples density also justified the change to $15 \mathrm{~mL}$ of solvent, instead of the $10 \mathrm{~mL}$ originally used. 
Therefore, combining the sample amount of $2 \mathrm{~g}$ and the solvent volume of $15 \mathrm{~mL}$, the concentration was changed from the original 1 to $0.13 \mathrm{~g}$ sample per $\mathrm{mL}$ [55]. This combination lead to an efficient method, using minimal size sample to provide statistically reliable results, although taking into account the degree of sample homogeneity [55]. In this study, HHCB was detected above LOD in all samples analysed. Other studies with the same kind of products used similar concentrations: 0.06-0.15 [46], 0.02-0.1 [41], 0.012 -0.02 [27] and $0.003 \mathrm{~g}$ sample per $\mathrm{mL}$ [48].

\section{Effect of the homogenization time}

The homogenization time by vortex, after the solvent addition, is a crucial step to guarantee quantitative extraction yields. Three times were tested: $30 \mathrm{~s}, 1$ and $3 \mathrm{~min}$. The longer time proved to enhance the extraction and that should be attributed to the complexity of the matrices and that needed more time to homogenize with acetonitrile. Other extraction methods of HHCB in PCPs refer a shaking time of $3 \mathrm{~min}[46,48]$ or even $15 \mathrm{~min}$ [41]. An additional step of sonication for $10 \mathrm{~min}$ was added after the first vortex shaking to enhance extraction. The use of sonication $(20 \mathrm{~min})$ has been also described by other authors [27].

Effect of the salts addition

After acetonitrile addition, vortexing and sonication, salts were added in the partitioning/drying step, namely magnesium sulphate $\left(\mathrm{MgSO}_{4}\right)$ and sodium acetate. The first is a drying agent, which confers less polarity to the extract, originating the precipitation of certain polar compounds. Anastassiades et al. [55] proposed the use of $4 \mathrm{~g}$ of $\mathrm{MgSO}_{4}$ to dry a $10 \mathrm{~g}$ sample of fruits and vegetables with an water content between $80 \%$ and $95 \%$. Considering some formulations of PCPs (Table II), water content ranges from $1 \%$ to $92 \%$, which, for a $2 \mathrm{~g}$ sample, corresponds to 0.02 to $1.84 \mathrm{~g}$ of water. To ensure a better water removal, $6 \mathrm{~g} \mathrm{MgSO}_{4}$ was added. Larger quantities of $\mathrm{MgSO}_{4}$ could difficult vortexing due to the formation of conglomerates and could also increase temperature to $40-45^{\circ} \mathrm{C}$, compromising the extraction efficiencies [55]. Assuming that each $\mathrm{MgSO}_{4}$ molecule joins to seven water molecules, because magnesium sulphate heptahydrate is the most commonly found, $6 \mathrm{~g}$ of this drying agent on the partitioning/drying step and the additional $900 \mathrm{mg}$ on the clean-up step, as described earlier, enables a $7.2 \mathrm{~g}$ water removal. Even when water is used as cosolvent $(5 \mathrm{~mL}$ or $5 \mathrm{~g})$, this drying process results in a total water removal during the extraction of a wide range of products, including the PCPs analysed on the current study. The other partitioning step salt, sodium acetate, was used in this study instead of sodium chloride, because it increases the aqueous phase polarity, decreasing even more water solubility of the less polar compounds, which enhances the extraction of $\mathrm{HHCB}$.

\section{Effect of the sorbents}

The basic formulation of some PCPs include a large number of compounds (Table II) that are susceptible to be present in the extract and interfere in the chromatographic analysis. So, a dispersive-SPE clean-up step was performed with $300 \mathrm{mg}$ of PSA and $150 \mathrm{mg}$ of $\mathrm{C} 18$ sorbents. The PSA sorbent is used to remove sugars, fatty acids, organic acids and some pigments, whereas the C18 sorbent is used to remove lipids and non-polar interferences [55]. Sugars only found in toothpastes, at very low mass percentages, and so it will be easily removed. Fatty acids are commonly used in soaps production, appearing as alkali salts (result of saponification), and in some emulsions (lotion, cream, hair conditioner and toothpaste) as emulsifiers. Although no difficulties are expected in removing fatty acids from these PCPs, the high percentage of those compounds in soaps could be a problem in the clean-up step of the resulting extracts. The most used fatty acids for soap bar production are lauric acid, palmitic acid and oleic acid. Organic acids and alcohols are also extensively found in PCPs, but only the toothpaste could be difficult to clean due to the highest percentage (15-75\%) of those compounds. The main organic alcohols found on the toothpaste composition are sorbitol and glycerine, whereas acids, like benzoic acid and tartaric acid, are less common. Lipids and waxes are mainly found in lotions and creams, and the small quantities found (22\% max.) are expected to be easily removed with $\mathrm{C} 18$ sorbent. Pigmentation of PCPs is normally very discreet or inexistent, exception made for make-up formulations, some hair care products and toothpaste $[54,56]$. The analysed hair care product included in this study presented almost colourless extracts. The most coloured product was the toothpaste, but the final dispersive-SPE clean-up used in this study was sufficient to remove all the pigments from the resulting extract, validating therefore the use of the sorbents and the amounts previewed. GCB is the sorbent proposed for intensively coloured extracts [55], but it was found not necessary because clean extracts were obtained using PSA and C18 sorbents.

Table II Content ranges (\%) of some group of compounds and $\mathrm{pH}$ ranges found in the composition of typical personal care products (PCPs) [54, 56]

\begin{tabular}{|c|c|c|c|c|c|c|c|c|c|c|}
\hline \multirow[b]{2}{*}{ PCPs } & \multicolumn{10}{|l|}{ Content } \\
\hline & Water (\%) & Sugars (\%) & Fatty acids (\%) & $\begin{array}{l}\text { Organic acids } \\
\text { and alcohols (\%) }\end{array}$ & $\begin{array}{l}\text { Lipids and } \\
\text { waxes (\%) }\end{array}$ & Pigments (\%) & $\begin{array}{l}\text { Perfumed } \\
\text { oils (\%) }\end{array}$ & $\begin{array}{l}\text { Flavour } \\
\text { oils (\%) }\end{array}$ & Others (\%) & $\mathrm{pH}$ \\
\hline Body Lotion & $64-82$ & - & $0-1.5$ & $3.8-4.0$ & $3-30$ & - & q.s. & - & $0.7-1.8$ & $5-6$ \\
\hline Body Cream & $29-70$ & - & $0-4$ & $2-30$ & $2-47$ & - & q.s. & - & $3-64$ & $5-6$ \\
\hline Shampoo & $39-70$ & - & - & $1-10$ & $0.4-3$ & q.s. & q.s. & - & $30-61$ & $5.5-8.5$ \\
\hline Bar soap & $1-15$ & - & 90-98 (salt) & - & - & - & $0.5-2$ & - & $0.6-1.35$ & $8-10$ \\
\hline Hair Conditioner & 89-92 & - & $0-0.5$ & $4-5$ & $0-0.5$ & q.s. & 0.4 & - & $2-3$ & $3.5-5$ \\
\hline Toothpaste & $26-43$ & $0-0.4$ & $0-0.5$ & $15-75$ & - & $0-0.01$ & - & $1.0-1.1$ & $19-52$ & $4-8$ \\
\hline
\end{tabular}

q.s., quantum satis; quantum sufficit, a Latin phrase used in prescription writing that means 'a sufficient quantity'. 

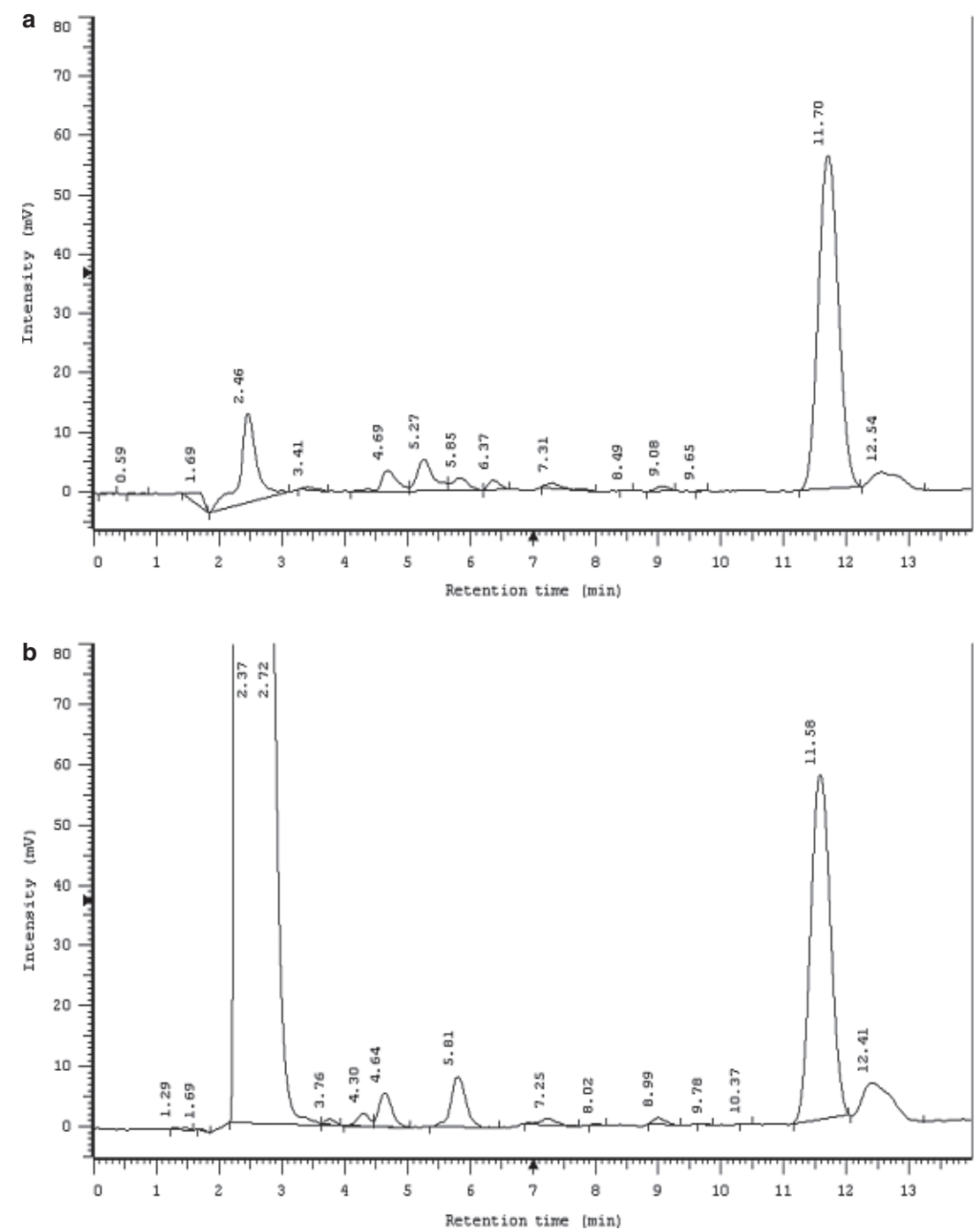

Figure 3 Fluorescence chromatograms of (a) a galaxolide standard (0.601 $\mathrm{mg} \mathrm{kg}^{-1}$ sample) prepared in mobile phase and (b) an extract of a body cream (detected concentration of $68.27 \mathrm{mg} \mathrm{kg}^{-1}$ sample, dilution factor of $1: 100$ in mobile phase).

The resulting chromatograms for the extraction method proposed in this study proved an excellent resolution for HCCB peak, with no interferents in the vicinity (Fig. 3). The final extraction conditions were therefore:

- $2 \mathrm{~g}$ of sample (with pre-treatment in a mortar for solid samples);

- $5 \mathrm{~mL}$ of water as cosolvent, followed by vortexing during $3 \mathrm{~min}$;

- $15 \mathrm{~mL}$ of acetonitrile as extraction solvent, followed by vortexing during $3 \mathrm{~min}$ and sonication for $10 \mathrm{~min}$;

- drying/partitioning step with $6.0 \mathrm{~g} \mathrm{MgSO}_{4}$ and $1.5 \mathrm{~g}$ sodium acetate, centrifuged for $10 \mathrm{~min}$ at $3700 \mathrm{rpm}$

- dispersive-SPE clean-up of the resulting upper layer with $900 \mathrm{mg} \mathrm{MgSO}_{4}, 300 \mathrm{mg}$ PSA and $150 \mathrm{mg} \mathrm{C18}$, centrifuged for $10 \mathrm{~min}$ at $1147.9 \mathrm{~g}$-force:

- extracts (upper layer) were preserved in PP tubes stored in a freezer $\left(-18^{\circ} \mathrm{C}\right)$.
Stability assays were performed with a standard solution (1.002 $\mathrm{mg} \mathrm{kg}^{-1}$ sample) stored in several conditions, and 8months stability was confirmed, whether the standard solution is in glass or PP tubes, each one stored in refrigerator $\left(4^{\circ} \mathrm{C}\right)$ and freezer $\left(-18^{\circ} \mathrm{C}\right)$.

\section{Chromatographic analysis and method validation}

The fluorescence chromatograms of an HHCB standard (0.601 $\mathrm{mg} \mathrm{kg}^{-1}$ sample) and the extract of a commercially available body cream are shown in Fig. 3. The HHCB peak is well identified when comparing these two chromatograms, with a retention time of about $12 \mathrm{~min}$. This main peak is followed, in all analysed chromatograms, by a small and non-symmetrical peak (12.5 min retention time), that has been described as a by-product of the technical synthesis of HHCB. The proposed analytical method is 
Table III Galaxolide (HHCB) concentration $\left(\mathrm{mg} \mathrm{kg}^{-1}\right.$ sample) found for each personal care product (PCP) analysed on this study, and recoveries (\%) found for each used HHCB spike level ( $\mathrm{mg} \mathrm{kg}^{-1}$ sample)

\begin{tabular}{|c|c|c|c|}
\hline PCPs & $\begin{array}{l}\text { ННСВ } \\
\text { concentration } \\
\text { (mg kg }{ }^{-1} \text { sample) }\end{array}$ & $\begin{array}{l}\text { HHCB spike level } \\
{\text { ( } \mathrm{mg} \mathrm{kg}^{-1} \text { sample) }}^{*}\end{array}$ & $\begin{array}{l}\text { Recovery } \\
(\%)\end{array}$ \\
\hline Body lotion & $7.31 \pm 0.85$ & - & - \\
\hline \multirow[t]{3}{*}{ Body cream } & $68.27 \pm 1.97$ & 5.8 & 95 \\
\hline & & 14.7 & 90 \\
\hline & & 29.4 & 83 \\
\hline Perfumed body cream & $280.78 \pm 8.19$ & - & - \\
\hline Shampoo & $87.35 \pm 2.45$ & 29.4 & 80 \\
\hline Hair conditioner $^{\dagger}$ & $28.90 \pm 1.10$ & 29.4 & 90 \\
\hline Soap bar & $2.48 \pm 0.61$ & 29.4 & 65 \\
\hline \multirow[t]{2}{*}{ Toothpaste $^{\dagger}$} & $0.04 \pm 0.01$ & 14.7 & 73 \\
\hline & & 29.4 & 80 \\
\hline
\end{tabular}

${ }^{\star}$ Extract 100 times diluted before analysis. 'Extraction made with water as cosolvent.

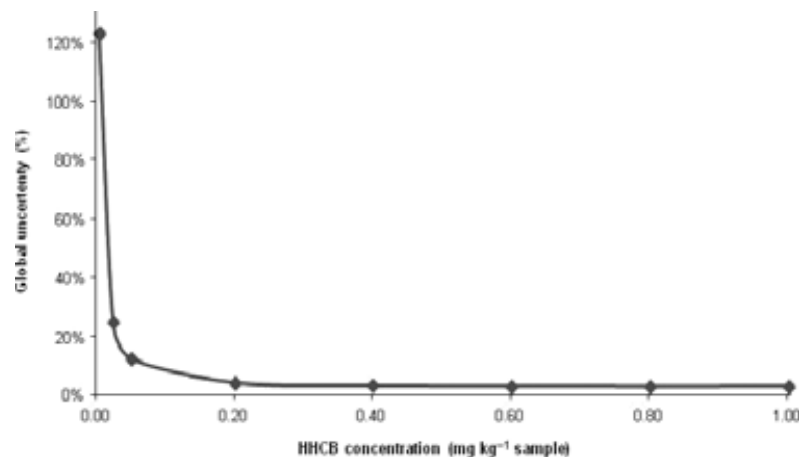

Figure 4 Global uncertainty (\%) of the current method, associated to galaxolide (HHCB) concentration ( $\mathrm{mg} \mathrm{kg}^{-1}$ sample) on personal care products, estimated accordingly to EURACHEM/CITAC Guide [58]. able to rapidly quantify $\mathrm{HHCB}$ when compared with other ones with larger retention times and more complex extraction procedure for HHCB (Table I).

A calibration curve was constructed by plotting the peak areas of eight standard solutions against the respective galaxolide concentrations. The linearity range was from 0.005 to $1.002 \mathrm{mg} \mathrm{kg}^{-1}$ sample, with an $R^{2}$ of 0.999 .

The limit of detection, LOD, obtained considering a three times signal-to-noise ratio, was $0.001 \mathrm{mg} \mathrm{kg}^{-1}$ sample $\left(0.22 \mu \mathrm{g} \mathrm{L}^{-1}\right)$, whereas the limit of quantification, limits of quantification (LOQ), obtained considering a ten times signal-to-noise ratio, was $0.004 \mathrm{mg} \mathrm{kg}^{-1}$ sample $\left(0.76 \mu \mathrm{g} \mathrm{L}^{-1}\right)$. These limits are below the $5 \mu \mathrm{g} \mathrm{L}^{-1}$ LOD of the original LLE with HPLC-FL detection method [49], as well the $49 \mathrm{mg} \mathrm{L}^{-1} \mathrm{LOD}$ and a $147 \mathrm{mg} \mathrm{L}^{-1} \mathrm{LOQ}$ of a LLE with detection based on enantiomeric separation by a capillary electrophoresis method [48]. Only methods using LLE with GC-MS detection could achieve such low limits (Table I).

The repeatability was evaluated by the coefficient of variation (CV) of the peak area of a standard solution injected six times on the same day at three levels of concentration: $11.3 \%$ (0.005 mg kg ${ }^{-1}$ sample), $0.9 \%$ (0.401 $\mathrm{mg} \mathrm{kg}^{-1}$ sample) and $0.7 \%$ (1.002 $\mathrm{mg} \mathrm{kg}^{-1}$ sample). These results are comparable with those presented by a capillary electrophoresis method [48]. An intermediate precision of $2.5 \%$ was obtained by the CV for six independent extractions of the same sample.

Accuracy, evaluated by the recovery percentage after spiking additions at different concentrations to the different samples, was within the range of $65 \%$ (soap bar) to $95 \%$ (body cream) as may be seen in Table III. These recovery results are consistent with other studies (Table I) $[27,46,48,50]$. The lower recovery found for the soap bar may be attributed to the high alkalinity of soaps, with $\mathrm{pH}$ values between 8 and 10. In fact, the $\mathrm{pH}$ values of the other products are lower (Table II), and the recoveries found for those products were higher, which may indicate that extraction or detection of HHCB is better at acidic or neutral conditions. Additionally, the degradation of HHCB to its transformation products, HHCB-lactone or the respective acid, is pH-dependent [57]. So, to evaluate the influence of $\mathrm{pH}$ on $\mathrm{HHCB}$ detection, three standards were prepared at different $\mathrm{pH}$ values: $\mathrm{pH} 4.0, \mathrm{pH} 7.0$ and $\mathrm{pH} 10.0$. The CV between HHCB concentration found for each standard and a normal standard (prepared in mobile phase) was 3\% maximum, revealing that $\mathrm{pH}$ has no influence on $\mathrm{HHCB}$ detection. Recovery

Table IV Estimated daily dermal exposure to $\operatorname{HHCB}\left(\mu \mathrm{g}\right.$ day $\left.{ }^{-1}\right)$ using the analysed personal care products

\begin{tabular}{|c|c|c|c|c|c|}
\hline Personal care products & Application site & Exposure route & $\begin{array}{l}\text { ННСВ } \\
\text { concentration } \\
\left(\mu \mathbf{g ~ g}^{-1} \text { sample) }\right.\end{array}$ & $\begin{array}{l}\text { Mean daily } \\
\text { application } \\
\text { (g sample per day) }\end{array}$ & $\begin{array}{l}\text { Estimated } \\
\text { daily HHCB } \\
\text { retention }\left(\mu \mathrm{g} \mathrm{day}^{-1}\right)^{\dagger}\end{array}$ \\
\hline Body lotions and creams & Whole body (includes face and hands) & Dermal & $105.72^{\ddagger}$ & 8.0 & 845.8 \\
\hline Shampoo & Scalp, neck and hands & Dermal & 69.88 & 8.0 & 55.90 \\
\hline Hair conditioner & Hair tips and hands & Dermal & 26.01 & 4.0 & 1.040 \\
\hline Soap bar & Whole body (includes face and hands) & Dermal & 2.48 & 5.0 & 1.240 \\
\hline Toothpaste & Perioral region and mouth mucous membranes & Dermal and oral & 0.03 & 2.0 & 0.0060 \\
\hline \multicolumn{5}{|c|}{ Estimated daily dermal exposure to ННСВ $\left(\mu \mathrm{g}_{\text {day }^{-1}}\right)$} & 904.0 \\
\hline
\end{tabular}

${ }^{*}$ Estimated values based on a previous studies [40, 51, 52, 61]

${ }^{\dagger}$ Retention factors of $100 \%$ for body lotions and creams, $1 \%$ for hair conditioner and $10 \%$ for the other PCPs [40].

"Mean HHCB concentration of the three body lotions/ creams analysed on this study. 
tests performed for a body cream, a shampoo and a bar soap, extracted with water (cosolvent) and acetonitrile, achieved mean recoveries of $98 \%, 81 \%$ and $53 \%$, respectively, when an $\mathrm{HHCB}$ spike of $29.4 \mathrm{mg} \mathrm{kg}^{-1}$ sample and a 100 times dilution of final extracts were used. These results seem to indicate that the use of water as a cosolvent does not change the method efficiency for these products, once similar results were obtained when the extraction was performed only with acetonitrile.

Dilution of extracts was performed whenever galaxolide concentration exceeds the calibration ranging. The influence of this dilution on the precision and accuracy was tested with a body cream extract (68.27 $\mathrm{mg} \mathrm{kg}^{-1}$ ) diluted $1: 100,1: 200$ and $1: 400$. The resulting concentrations had a $\mathrm{CV}$ of $3.4 \%$ between them, which proves that dilution has no effect on the results.

The effect of matrix interferences was proved negligible for a body cream, with different spiked HHCB concentrations, because the obtained areas of the spiked samples lied within the linear fit limits of the calibration curve. The recovery percentages obtained were $95 \%, 90 \%$ and $83 \%$ for HHCB spike levels of $0.06,0.15$ and $0.29 \mathrm{mg} \mathrm{kg}^{-1}$ sample, respectively.

The global uncertainty was calculated using the bottom-up approach, adopted by the International Organization for Standardization (ISO) and also adapted by the EURACHEM/CITAC Guide [58]. According to this approach, there are four main individual sources of uncertainty that must be taken into account, namely the standard preparation uncertainty, the calibration curve uncertainty, the precision uncertainty and the accuracy uncertainty, as already described by Ratola et al. [59]. This method presents a global uncertainty ranging from $25 \%$ to $3 \%$ for concentrations from 0.0251 to $1.002 \mathrm{mg} \mathrm{kg}^{-1}$ sample, and only the lowest concentration (0.005 $\mathrm{mg} \mathrm{kg}^{-1}$ sample) presents a high uncertainty of $123 \%$ (Fig. 4).

\section{Galaxolide in personal care products and daily exposure estimates}

The developed method was applied to the determination of $\mathrm{HHCB}$ in seven PCPs. HHCB was detected in all products analysed, within a wide range of concentrations (Table III) consistent with other studies (Table I). The lowest value was found on the toothpaste, $0.04 \pm 0.01 \mathrm{mg} \mathrm{kg}^{-1}$ sample, and the highest one in the perfumed body cream, $280.78 \pm 8.19 \mathrm{mg} \mathrm{kg}^{-1}$ sample (Table III). All the concentrations presented in Table III are corrected with the recovery percentage. For all of the three body creams and lotions, a mean recovery of $89 \%$ was used, a value that resulted from the three recovery percentages obtained for the body cream.

Considering a typical adult consume profile, estimation of a daily exposure to HHCB was performed, exclusively using the analysed PCPs as sources. The formulated hypothesis, as the application site, mean daily application amount and percentage of skin retention are found in Table IV. The retention factors were based on a previous study [40] that as similar products: $100 \%$ for leave-on products (body lotions and creams) and 10\% for rinse off products (shampoo, soap bar and toothpaste). For the hair conditioner, it was assumed a retention factor lower than the other rinse off PCPs, of only $1 \%$, because a correct application is only made on hair tips and not on scalp. The final daily dermal exposure for each PCPs was calculated multiplying the concentration of $\mathrm{HHCB}$ on the product for the daily application amount and the retention factor. A total daily dermal exposure to $\mathrm{HHCB}$ of $904 \mu \mathrm{g} \mathrm{day}^{-1}$ was found, which was bellow other published results: $3060 \mu \mathrm{g} \mathrm{day}^{-1}$ [47], 25100 [60] and $23700 \mu \mathrm{g} \mathrm{day}^{-1}$ [46]. Additionally, assuming a total evaporation of $22 \%$ of $\mathrm{HHCB}$ [42], only $705 \mu \mathrm{g} \mathrm{day}^{-1}$ is effectively retained on the skin surface and is able to be systemically absorbed. The human skin absorption amount of HHCB has been reported to be about $0.1 \%$ [42]. Assuming that this is the absorption average rate for a normal adult skin, the estimated global systemic human exposure to HHCB may be considered very low, although other studies are required specially when dealing with sensitive and more permeable skins, like children's or senior's.

\section{Conclusions}

As a result of this study, a quick and easy method was developed for the analysis of galaxolide in PCPs. This method showed an excellent global uncertainty of $3 \%$ when concentrations of the products studied were above $2 \mathrm{mg} \mathrm{kg}^{-1}$ sample. All analysed products contained $\mathrm{HHCB}$ at concentrations ranging from $0.04 \pm 0.01 \mathrm{mg} \mathrm{kg}^{-1}$ sample, on the toothpaste, to $280.78 \pm 8.19 \mathrm{mg} \mathrm{kg}^{-1}$ sample, on the perfumed body cream. A daily human exposure to $\mathrm{HHCB}$ of $904 \mu \mathrm{g}$ day $^{-1}$ was estimated considering dermal application of these PCPs as the only source. This validated analytical method will enable the future characterization of the presence of galaxolide in a huge variety of PCPs, to evaluate the trends of consumption and human exposure to this chemical.

\section{Acknowledgement}

This study was developed at Laboratório de Engenharia de Processos, Ambiente e Energia, (LEPAE), Faculdade de Engenharia da Universidade do Porto. The project was supported by Instituto Politécnico do Porto (IPP) and was also financed by Fundação para a Ciência e a Tecnologia through a doctoral grant (SFRH/BD/ 70945/2010).

\section{References}

1. Arbulu, M., Sampedro, M.C., Unceta, N., Gómez-Caballero, A., Goicolea, M.A. and Barrio, R.J. A retention time locked gas chromatography-mass spectrometry method based on stir-bar sorptive extraction and thermal desorption for automated determination of synthetic musk fragrances in natural and wastewaters. J. Chromatogr. A 1218(20), 3048-3055 (2011).
2. OSPAR Comission. OSPAR Background Document on Musk Xylene and Other Musks. ISBN 1-904426-36-0 (2004).

3. Balk, F. and Ford, R.A. Environmental risk assessment for the polycyclic musks AHTN and HHCB in the EU: I. Fate and exposure assessment. Toxicol. Lett. 111(1-2), 57-79 (1999).

4. HERA. HERA (Human and Environmental Risk Assessment on Ingredients of Household Cleaning Products) Environmental Risk
Assessment Polycyclic Musks AHTN (CAS 1506-02-1) and HHCB (CAS 122-05-05). (2004).

5. Clara, M., Gans, O., Windhofer, G. et al. Occurrence of polycyclic musks in wastewater and receiving water bodies and fate during wastewater treatment. Chemosphere $\mathbf{8 2}$ (8), 1116-1123 (2011).

6. Chen, D., Zeng, X., Sheng, Y., Bi, X., Gui, H., Sheng, G., Fu, J. The concentrations and distribution of polycyclic musks in a typical 
cosmetic plant. Chemosphere 66(2), 252258 (2007).

7. Hu, Z., Shi, Y., Zhang, S., Niu, H. and Cai, Y. Assessment of synthetic musk fragrances in seven wastewater treatment plants of Beijing, China. Bull. Environ. Contam. Toxicol. 86(3), 302-306 (2011).

8. Eschke, H.-D. Synthetic musks in different water matrices. In: The Handbook of Environmental Chemistry (Rimkus, G., ed.), pp. 1728. Springer Berlin, Heidelberg (2004).

9. Hu, Z., Shi, Y. and Cai, Y. Reprint of: concentrations, distribution, and bioaccumulation of synthetic musks in the Haihe River of China. Chemosphere 85(2), 262-267 (2011).

10. Moldovan, Z., Chira, R. and Alder, A. Environmental exposure of pharmaceuticals and musk fragrances in the Somes River before and after upgrading the municipal wastewater treatment plant Cluj-Napoca, Romania. Environ. Sci. Pollut. Res. Int. 16, 46-54 (2009).

11. Ramírez, N., Borrull, F. and Marcé, R.M. Simultaneous determination of parabens and synthetic musks in water by stir-bar sorptive extraction and thermal desorptiongas chromatography-mass spectrometry. J. Sep. Sci. 35(4), 580-588 (2012).

12. Silva, A. and Nogueira, J. Stir-bar-sorptive extraction and liquid desorption combined with large-volume injection gas chromatography-mass spectrometry for ultra-trace analysis of musk compounds in environmental water matrices. Anal. Bioanal. Chem. 396(5), 1853-1862 (2010).

13. Yang, C.-Y. and Ding, W.-H. Determination of synthetic polycyclic musks in aqueous samples by ultrasound-assisted dispersive liquid-liquid microextraction and gas chromatography-mass spectrometry. Anal. Bioanal. Chem. 402(4), 1723-1730 (2012).

14. Yang, J.-J. and Metcalfe, C.D. Fate of synthetic musks in a domestic wastewater treatment plant and in an agricultural field amended with biosolids. Sci. Total Environ. 363(1-3), 149-165 (2006).

15. Bruchet, A., Hochereau, C., Picard, C., Decottignies, V., Rodrigues, J. and Janex-Habibi, M. Analysis of drugs and personal care products in French source and drinking waters: the analytical challenge and examples of application. Water Sci. Technol. 52(8), 53-61 (2005).

16. Kupper, T., Berset, J.D., Etter-Holzer, R., Furrer, R. and Tarradellas, J. Concentrations and specific loads of polycyclic musks in sewage sludge originating from a monitoring network in Switzerland. Chemosphere $\mathbf{5 4}$ (8), 1111-1120 (2004).
17. Peck, A., Kucklick, J. and Schantz, M. Synthetic musk fragrances in environmental standard reference materials. Anal. Bioanal. Chem. 387(7), 2381-2388 (2007).

18. Rimkus, G.G. Polycyclic musk fragrances in the aquatic environment. Toxicol. Lett. 111 (1-2), 37-56 (1999).

19. Wu, S.-F. and Ding, W.-H. Fast determination of synthetic polycyclic musks in sewage sludge and sediments by microwave-assisted headspace solid-phase microextraction and gas chromatography-mass spectrometry. J. Chromatogr. A 1217(17), 2776-2781 (2010).

20. Aschmann, S., Arey, J., Atkinson, R. and Simonich, S. Atmospheric lifetimes and fates of selected fragrance materials and volatile model compounds. Environ. Sci. Technol. 35 (18), 3595-3600 (2001).

21. Fromme, H., Lahrz, T., Piloty, M., Gebhart, H., Oddoy, A. and Rüden, H. Occurrence of phthalates and musk fragrances in indoor air and dust from apartments and kindergartens in Berlin (Germany). Indoor Air 14 (3), 188-195 (2004).

22. Ramírez, N., Marcé, R.M. and Borrull, F. Development of a thermal desorption-gas chromatography-mass spectrometry method for determining personal care products in air. $J$. Chromatogr. A 1217(26), 4430-4438 (2010).

23. Regueiro, J., Garcia-Jares, C., Llompart, M., Lamas, J.P. and Cela, R. Development of a method based on sorbent trapping followed by solid-phase microextraction for the determination of synthetic musks in indoor air. J. Chromatogr. A 1216(14), 2805-2815 (2009).

24. Sofuoglu, A., Kiymet, N., Kavcar, P. and Sofuoglu, S.C. Polycyclic and nitro musks in indoor air: a primary school classroom and a women's sport center. Indoor Air 20(6), 515-522 (2010).

25. Peck, A.M. and Hornbuckle, K.C. Synthetic musk fragrances in Lake Michigan. Environ. Sci. Technol. 38(2), 367-382 (2004).

26. Upadhyay, N., Sun, Q., Allen, J.O., Westerhoff, P. and Herckes, P. Synthetic musk emissions from wastewater aeration basins. Water Res. 45(3), 1071-1078 (2011).

27. Lu, Y., Yuan, T., Yun, S., Wang, W. and Kannan, K. Occurrence of synthetic musks in indoor dust from China and implications for human exposure. Arch. Environ. Contam. Toxicol. 60(1), 182-189 (2011).

28. Kannan, K., Reiner, J.L., Yun, S.H., Perrotta, E.E., Tao, L., Johnson-Restrepo, B. et al. Polycyclic musk compounds in higher trophic level aquatic organisms and humans from the United States. Chemosphere 61(5), 693-700 (2005).
29. Mottaleb, M.A., Usenko, S., O’Donnell, J.G., Ramirez, A.J., Brooks, B.W. and Chambliss, C.K. Gas chromatography-mass spectrometry screening methods for select UV filters, synthetic musks, alkylphenols, an antimicrobial agent, and an insect repellent in fish. J. Chromatogr. A 1216(5), 815-823 (2009).

30. Ramirez, A., Brain, R., Usenko, S. et al. Occurrence of pharmaceuticals and personal care products in fish: results of a national pilot study in the United States. Environ. Toxicol. Chem. 28(12), 2587-2597 (2009).

31. Subedi, B., Mottaleb, M.A., Chambliss, C.K. and Usenko, S. Simultaneous analysis of select pharmaceuticals and personal care products in fish tissue using pressurized liquid extraction combined with silica gel cleanup. J. Chromatogr. A 1218(37), 62786284 (2011).

32. HERA. HERA (Human and Environmental Risk Assessment on Ingredients of Household Cleaning Products) Risk Assessment of HHCB $\quad(1,3,4,6,7$-hexahydro-4, 6, 6,7,8-hexamethylcyclopenta- $\gamma$-2-benzopyran and related isomers). (2004).

33. Hutter, H.P., Wallner, P., Hartl, W., Uhl, M., Lorbeer, G., Gminski, R., Kundi, M. Higher blood concentrations of synthetic musks in women above fifty years than in younger women. Int. J. Hyg. Environ. Health 213(2), 124-130 (2010).

34. Hutter, H.P., Wallner, P., Moshammer, H., Hartl, W., Sattelberger, R., Lorbeer, G., Kundi, M. Synthetic musks in blood of healthy young adults: relationship to cosmetics use. Sci. Total Environ. 407(17), 4821-4825 (2009).

35. Hutter, H.P., Wallner, P., Moshammer, H., Hartl, W., Sattelberger, R., Lorbeer, G., Kundi, M. Blood concentrations of polycyclic musks in healthy young adults. Chemosphere 59(4), 487-492 (2005).

36. Kuklenyik, Z., Bryant, X.A., Needham, L.L. and Calafat, A.M. SPE/SPME-GC/MS approach for measuring musk compounds in serum and breast milk. J. Chromatogr. B Analyt. Technol. Biomed. Life Sci. 858(1-2), 177-183 (2007).

37. Liebl, B., Mayer, R., Ommer, S., Sönnichsen, C. and Koletzko, B. Transition of Nitro Musks and Polycyclic Musks into Human Milk in: Short and Long Term Effects of Breast Feeding on Child Health (Koletzko, B., Michaelsen, K.F. and Hernell, O., eds), pp. 289-305. Springer, USA (2002).

38. Reiner, J., Wong, C., Arcaro, K. and Kannan, K. Synthetic musk fragrances in human milk from the United States. Environ. Sci. Technol. 41(11), 3815-3820 (2007). 
39. Schlumpf, M., Kypke, K., Wittassek, M. et al. Exposure patterns of UV filters, fragrances, parabens, phthalates, organochlor pesticides, PBDEs, and PCBs in human milk: correlation of UV filters with use of cosmetics. Chemosphere 81(10), 1171-1183 (2010).

40. Cadby, P.A., Troy, W.R. and Vey, M.G.H. Consumer exposure to fragrance ingredients: providing estimates for safety evaluation. Regul. Toxicol. Pharmacol. 36(3), 246-252 (2002).

41. Reiner, J.L. and Kannan, K. A survey of polycyclic musks in selected household commodities from the United States. Chemosphere 62(6), 867-873 (2006).

42. Ford, R.A., Hawkins, D.R., Schwarzenbach, R. and Api, A.M. The systemic exposure to the polycyclic musks, AHTN and HHCB, under conditions of use as fragrance ingredients: evidence of lack of complete absorption from a skin reservoir. Toxicol. Lett. 111(1-2), 133-142 (1999).

43. SCCNFP. Opinion of the Scientific Committee on Cosmetic Products and Non-food Products (SCCNFP) Intended for Consumers. SCCNFP, Brussels (2002).

44. Api, A.M. and Ford, R.A. Evaluation of the oral subchronic toxicity of HHCB (1,3,4,6,7,8-hexahydro-4,6,6,7,8,8-hexamethylcyclopenta- $\gamma$-2-benzopyran) in the rat. Toxicol. Lett. 111(1-2), 143-149 (1999).

45. Rogers, R., Isola, D., Jeng, C., Lefebvre, A. and Smith, L. Simulated inhalation levels of fragrance materials in a surrogate air freshener formulation. Environ. Sci. Technol. 39 (20), 7810-7816 (2005).

46. Roosens, L., Covaci, A. and Neels, H. Concentrations of synthetic musk compounds in personal care and sanitation products and human exposure profiles through dermal application. Chemosphere 69(10), 15401547 (2007).

47. Lu, Y., Yuan, T., Wang, W. and Kannan, K. Concentrations and assessment of exposure to siloxanes and synthetic musks in personal care products from China. Environ. Pollut. 159(12), 3522-3528 (2011).

48. Martínez-Girón, A.B., Crego, A.L., González, M.J. and Marina, M.L. Enantiomeric separation of chiral polycyclic musks by capillary electrophoresis: application to the analysis of cosmetic samples. J. Chromatogr. A 1217(7), 1157-1165 (2010).

49. Schüssler, W. and Nitschke, L. Determination of trace amounts of Galaxolide ${ }^{\circledR}$ (HHCB) by HPLC. Fresenius J. Anal. Chem. 361(2), 220-221 (1998).
50. Zhang, X., Yao, Y., Zeng, X. et al. Synthetic musks in the aquatic environment and personal care products in Shanghai, China. Chemosphere 72(10), 1553-1558 (2008).

51. Loretz, L., Api, A.M., Barraj, L. et al. Exposure data for personal care products: hairspray, spray perfume, liquid foundation, shampoo, body wash, and solid antiperspirant. Food Chem. Toxicol. 44(12), 20082018 (2006).

52. Loretz, L.J., Api, A.M., Barraj, L.M. et al. Exposure data for cosmetic products: lipstick, body lotion, and face cream. Food Chem. Toxicol. 43(2), 279-291 (2005).

53. Regulation of the European Parliament and of the Council on Cosmetic Products (recast) PE-CONS 3623/09, Brussels (2009).

54. Umbach, W. Cosmetics and Toiletries, 1st edn (Sharp, D., ed.). Ellis Horwood Limited, England (1991).

55. Anastassiades, M. and Lehotay, S.J. Fast and easy multiresidue method employing acetonitrile extraction/partitioning and "Dispersive Solid-Phase Extraction" for the determination of pesticide residues in produce. J. AOAC Int. 86(2), 412-431 (2003).

56. Williams, S.D. Chemistry and Technology of the Cosmetics and Toiletries Industry, 2nd edn. Blackie Academic \& Professional, UK (1996).

57. Bester, K. Analysis of musk fragrances in environmental samples. J. Chromatogr. A 1216(3), 470-480 (2009).

58. Ellison, S.L.R., Rosslein, M. and Williams, A. EURACHEM/CITAC Guide- Quantifying Uncertainty in Analytical Measurement, 2nd edn. EURACHEM/CITAC Working Group, United Kingdom (2000).

59. Ratola, N., Martins, L. and Arminda, A. Ochratoxin $\mathrm{A}$ in wines-assessing global uncertainty associated with results. Anal. Chim. Acta 513, 319-324 (2004).

60. Ford, R. The human safety of the polycyclic musks AHTN anh HHCB in fragrances - a review. Deut. Lebensm. Rundsch. 94, 268275 (1998).

61. Hall, B., Tozer, S., Safford, B. et al. European consumer exposure to cosmetic products, a framework for conducting population exposure assessments. Food Chem. Toxicol. 45 (11), 2097-2108 (2007). 